\title{
Shopaholic Phenomenon, Choice of Shopping Place and the Development of Megamalls in Ibadan, Nigeria
}

\author{
Olawale Yinusa Olonade ${ }^{1}$, Dauda Aderemi Busari², David Imhonopi ${ }^{3}$, Tayo Ola George ${ }^{4}$, \\ Charles Tunde Iruonagbe ${ }^{5}$ and Christiana Olufunke Adetunde ${ }^{6}$ \\ 1,3,4,5,6 Department of Sociology, Covenant University, Ota, Nigeria \\ ${ }^{2}$ Department of Sociology, University of Ibadan, Ibadan, Nigeria
}

Correspondence should be addressed to: Olawale Yinusa; olawale.olonade@covenantuniversity.edu.ng

Received date: 2 March 2020; Accepted date: 17 December 2020; Published date: 15 January 2021

Copyright (C 2021. Olawale Yinusa Olonade, Dauda Aderemi Busari, David Imhonopi, Tayo Ola George, Charles Tunde Iruonagbe and Christiana Olufunke Adetunde. Distributed under Creative Commons Attribution 4.0 International CCBY 4.0

\begin{abstract}
Shopping activities in the $21^{\text {st }}$ century are taking a social dimension rather than mere commercial activities. This is evident in the importance of consumer attachment to shopping and choice of shopping place, which necessitated the increase in the number of megamalls in many cities globally, including Nigeria. This study examined the shopaholic phenomenon, choice of shopping place, and the development of megamalls in Ibadan, Nigeria. The study was empirical using both quantitative and qualitative methods for data collection. Two hundred sixteen copies of the questionnaire were administered to mall customers, while an In-depth interview was conducted for six mall operators cut across malls in Ibadan. Statistical Package for Social Sciences using frequency tables, percentages, and histogram charts was used for analysis. The study revealed that most respondents choose Megamall as their shopping place, and there is a connection between the shopaholic phenomenon, choice of shopping place, and the development of megamalls. The conducive and serene environment which megamalls portray has wooed many customers in the urban areas to choose it as their priority as it concerns shopping, and that has gone a long way to enhance the development and sustainability of megamalls in Nigeria. Most customers patronize malls because of their innate love of shopping, ostentatious life, and showy life to impress friends and well-wishers. The glamour and fascination that megamalls display cannot be gotten in retail shops or open markets. Customers are delighted with their experiences in the megamalls that account for their continued patronage of the megamalls over other shopping alternatives.
\end{abstract}

Keyword: Megamall, Shopaholic, Shopping place, Retail Stores.

Cite this Article as: Olawale Yinusa Olonade, Dauda Aderemi Busari, David Imhonopi, Tayo Ola George, Charles Tunde Iruonagbe and Christiana Olufunke Adetunde (2021)," Shopaholic Phenomenon, Choice of Shopping Place and the Development of Megamalls in Ibadan, Nigeria", IBIMA Business Review, Vol. 2021 (2021), Article ID 280834, D0I: $10.5171 / 2021.280834$ 


\section{Introduction}

Shopping is a viable business endeavor that is limited to consumption and entails a social dimension. It is a social practice which reflects people's lifestyle. Megamalls create a serene environment similar to urban centers with social activities in a different arrangement where shopping activities occur. The essence of Megamalls can be found in a variety of choices individuals make in their daily lives. Streetlife is exciting, but people look for different things in megamalls. Megamall has become the most essential and popular interface where consumers and producers meet. It is a place that attracts vast throngs of people (Rousseau and Venter, 2014).

Trading activities remain a major key factor for developing cities and towns and the intensification of their desirability. The right to pursue commerce is very pivotal to this development. Market places seemed to be and are still persistent urban features (Cohen, 2006). Essentially, people's lives center around work and leisure. Various individuals by design must stop and exchange money for products and services that make work and play possible. Small shop centers connect lives more pleasantly as they have been the usual practice since the olden days till now, this grows into stable or semi-stable dwelling edifices and commercial arenas (Busari, Olonade \& Asamu, 2019).

Megamalls are usually a spacious arena with a blend of outdoor services with significant investment in seats, air conditioning, large space, and beautiful decors (Njoroge, 1995). Sourcing for markets and patrons is mostly by advertisement, special offers, and sponsorship to create brand loyalty among customers. Operators of shopping malls generally established arrangements for a franchise with multinational organizations that will also control the supply of raw materials used for goods, items, menu, and the manner of presentations and arrangements in sections. One of the implications of Megamall's continuous development is that proceeds made from sales by foreign-controlled chains are usually repatriated back to their countries. By implication, the proceeds and large income made are transferred out of the host economy, thereby amounting to labor loss for the country at large (Busari et al., 2019).

Home-made foods with the family dinner table's arrangement are progressively giving way for fast food takeaway consumption, with ease of purchase at the megamalls (Wikipedia, online dictionary, 2018). Most importantly, studies have shown that fast food consumption is connected to many diseases, including colorectal cancer, obesity, high cholesterol, and depression (Talwar, 2003). Many fast foods tend to be high in saturated fat, sugar, salt, and calories (EurekAlert, 2018). Critics of the mega malls have long warned about the perils of addiction to processed food, canned items, foreign products, expired materials, and other consumables. Although megamalls serve as essential places for shopping, entertainment, and social interaction in Nigeria, the centers are faced with dynamic shoppers' attitudes and a changeable competitive environment. The adventurous nature of most city dwellers make them to always move with the latest trend in town. In such an unstable situation, it is essential to understand and predict shopping mall performance. Thus, megamalls are faced with demands to adjust their marketing mix strategies to fit the latest market trends. These have originated from the changes in urban dwellers' consumption patterns, citizens' choice of shopping place, which have brought about irregular purchase decisions and extreme competition among the shopping malls and their development in different locations and environments.

\section{Review of Literature}

Sharma, Narang, Rajender, and Bhatia (2005) assert that shopaholism is a medical term for the uncontrollable craving for shopping activities. It is the same with the term 'oniomania,' from the Greek words onios (for sale) and mania (insanity). It is described as an 'impulse control disorder.' Ridgeway, Braga, Tita, and Pierce (2011) submit that approximately $8.9 \%$ of America's people experience this condition. Ostentatiousness is "a pretentious display meant to impress others" or a "boastful showiness" (Perkins, 2008). It attracts or seeks to attract attention, esteem, or envy, often by flamboyance or obviousness. It is excessively elaborate or noticeably characterized by, fond of, 
or evincing ostentation. Things, wealth, or knowledge portrayed as ostentatious seem to have put themselves on display; they are practically begging for attention. Ostentatious applies to items or buildings, which are luxurious, mansions, and fancy high-rises with marble columns. Some sets of people are ostentatious; they have lifestyles that connote spending extravagancy. Their consumption depicts the impressive things they buy. They attract attention not only because of quality but also for an implied luxury. Moreover, any amount of ostentation is wrong during tough economic times like these. It is more wrong than usual (Bhatia, 2005).

Megamall depicts conglomerates and chains of businesses in goods, services, vacation, and voluntary acts. An array of shops and wares lined up for purchase, fun catching, sightseeing, relationship building, and business transacting (Omoniyi, 2018). Megamall can be defined as a set of buildings that allow the public to walk from one unit to another as they go about exchanging goods and services for money. They are an extensive shopping area containing very many shops, cinemas, and restaurants. They are a vast shopping area containing very many shops, cinemas, and restaurants. It is a shopping type, and pleasure arcade commonly in the open air and connecting walkways end to end (Munich, 2004).

Standard practices in many Nigerian cities such as; Port Harcourt, Lagos, Uyo, Abuja, Umuahia, Jos, and Akure are constructing commercial precincts above or under the old road network. The implication of this is that the rich people in the society are disconnected from the paths of urban center areas, and the physical interaction among diverse cultural and social groups and their lifestyles and values become more irregular compared with that of an average person. Most megamalls have been planned to ensure adequate security, traffic, attention, and fashion-oriented culture rather than the interaction between individuals (Creel, 2006). Megamalls denote a different type of street or arcade in metropolitan commercial areas focused on pedestrians and helped by public transit. They depict an environment void of traffic situations that turn into a place where people can walk, sit, eat, and observe the various human activities around them (Ferdman, 2018). Several continuous blocks along a shopping street used by people on foot have consisted of pedestrian malls. They are formed by closing a street for vehicular traffic and improving pedestrian streets with new paving, street trees, street furnishings, and other amenities such as sculpture and fountains. The full-fledge Megamall provides visual continuity, a unique character, and helps create an image and sense of place for the consumers or people (Gürçel, 2003).

With most capital cities with one form of modern Megamall or the other, developers have increasingly targeted secondary cities to gain a first-mover advantage in these locations. Bidandi and Williams (2017) opined that developers are now concentrating on building well situated shopping malls rather than an open market as malls are suitable for the land economy policy. Megamalls also affords shoppers, patrons, and funseekers a complete and holistic opportunity to shop, play, catch fun, take shots, and do business with every day and easy-to-use technology and all within a short time Indeed, Megamalls' development plays a vital part in determining Africa's growing cities' future landscapes.

Before the ideas of megamalls emanated, it is clear that people subscribe to the old conventional means of doing trading activities. The buying and selling take place within the street through various forms and styles, which include; kiosk/stands, ware display, floor marketing, fast food center, hawking, stores, arcades, open or closed bazaars, pedestals, passages, quick service restaurants, and others (Chukuezi, 2010). This occurrence has stayed for a very long time, and it appears to be growing silently. It is called street vending or selling. Street vending can be defined as an easy, unorganized, and frequently non-registered economic activity in the developing world's fastgrowing cities. It is an essential part of urban economies worldwide, offering easy access to a wide range of goods and services in public spaces (Egharevba, Eguavon, Azuh, Iruonagbe \& Chiarzor, 2016). Street vending micro-economies are crucial for the economic planning and development of many communities. They involve in many trading activities, from fresh vegetables to prepared foods, from building materials to garments and crafts, from consumer electronics to auto repairs to haircuts (Rousseau and Venter, 2014).

Creel (2006) asserts that street vending businesses are usually owned and operated by individuals or families. Street food enterprises are generally small 
in size; require relatively specific skills, necessary facilities, and small amounts of capital. The street food vendors' marketing success depends exclusively on location and word-of-mouth promotion (Ferdman, 2018). Street vendors'

contribution to developing countries' economies has been underestimated and neglected (Rousseau and Venter, 2014) and replaced with a megamall, which provides a total, comprehensive buying and fun experiences for people at a go within the same arena. The significance of street vending has often been ignored because it is seen only as a dominant and distinctive component of a broad informal sector. There is increasing recognition that street vending plays a crucial socio-economic role in employment potential, providing particular income, particularly for women, and providing food at affordable costs to mainly the lower-income groups in the cities (Chukuezi, 2010).

Most street vendors offer the primary source of revenue for their families, providing food for their households, and paying school fees. However, despite their immense impacts on the socioeconomic wellbeing, street vendors are confronted with myriads of difficulties. They are mostly unrecognized as critical stakeholders in the economy, and when compared to other enterprises, they are limited instead of been given an enabling environment to thrive. Concerns of cleanliness and freshness usually discourage many people from eating street food or buying items (Mukhola, 2007). Due to a reasonable number of factors, such as; safety, hygiene, conducive and scintillating environment for play, fun and excitement, holistic buying, business expansions and connections, bulk buying, urban dwellers prefer patronizing megamalls than street vending economies.

With the advent of modernization, there is an evolution of arcades to malls and department stores into large supermarkets also. Small scale retailers and business owners wind up their trade activities as people opt for Megamall to buy cheap and foreign products and enjoy quality time with their families and friends. White and Sutton (2001) affirm that urban culture's characteristics include foreign relations, competitive behavior, and distant bloodlines. This unprecedented migration of people is predicted to continue at a more intensified level during the next few decades, escalating cities to sizes unimaginable only about a hundred years ago. Consequently, the growth of the world city population curve has up till recently followed a quadratic-hyperbolic pattern. Urbanization occurs because people move from rural areas (countryside) to urban areas (towns and cities). This usually occurs when a country is still developing. This applies to the people abandoning small street stores, groceries kiosk to urban areas where megamalls thrive.

\section{Theoretical Framework}

Modernization refers to a model of a transition from an orthodox era to modern society. It came up from sociologist Max Weber (1864-1920) and a shift in paradigm propounded by Harvard sociologist Talcott Parsons(1902-1979). The theory looks at some internal factors and mechanisms of a country in a new dimension. It identifies social factors capable of contributing to societies' societal growth and explaining societal evolution and development. It can be equated with the processes of urbanization, westernization, and industrialization. Kendall (2007) notes that Modernization is an overarching process of rationalization that sees the socio-cultural and political values heavily determine economic conditions in such a society.

Modernization theory submits that the wave of buying and selling in an organized, conducive, and friendly environment is not negotiable as the world is turning into a more relaxed and social-oriented setting. Due to people's nature and nonavailability, it becomes more convenient to shop, relate, and relax in an open arena. Society presents an atmosphere that makes people acclimatized, feel secured and homely, and purchase goods at relatively low prices. In the same vein, people are capturing this offer and turning the privileges into opportunities for themselves and their families. Rather than toeing the path of traditional societies, modernization has made human beings see reasons to change their shopping place and move to the trendy place of shopping. There is nothing that cannot be purchased or found in megamalls or relaxation centers. People pay obeisance to these centers on weekend and privilege holidays to unwind, celebrate, relate, meet people, and exchange business or relationship contacts, unlike the traditional display of goods or local stores that do not provide serenity freedom to relate and relax. 
Even in core oldies, goods were lined up by the roadside with symbols or price tags, and buyers pick and drop their pay without interaction and negotiation. Modernization frowns at this.

More so, critics of this theory submit that modernization has eroded traditional core values and practices. It has done more harm than good. It has preached westernization more than the orthodox and conventional means of getting things done devoid of crises, fraud, stealing, fighting, and other anti-social behaviors.

\section{Methods}

This descriptive study was conducted in Ibadan, southwest Nigeria. Ibadan was selected for this study because of the preponderance of megamalls in the Ibadan metropolis and Megamalls' increased patronage over retail shops in Ibadan. The study population were selected megamall costumers and megamall managers in the Ibadan metropolis. Secondary data were gathered through scholarly articles. Primary data were gathered through quantitative and qualitative techniques. Quantitative data were gathered with 216 copies of questionnaires administered to active megamall users (who must have been using megamalls in the past 12 months consecutively), while qualitative data were gathered with 6 IDIs (In-depth interviews) from megamall operators who are in the managerial cadre in the selected shopping malls in Ibadan. The study captured the views of both megamalls' customers and operators/managers of megamalls. Purposive and accidental sampling technique was used to select 216 respondents for the quantitative data in various megamalls in Ibadan Metropolis. Quantitative data were analyzed at a univariate level using SPSS, while the qualitative data were analyzed through content analysis and presented as ethnographic summaries. All the ethical issues were strictly taken into consideration. The principles of voluntary participation, anonymity, and confidentiality were observed. The respondents' rights to confidentiality and privacy were taken into consideration during the data collection.

\section{Findings and Discussions}

Table 1 below sociodemographic characteristics of the respondents. The table shows that a higher percentage of the respondents, 46.8\%, falls between $25-34$ years. This shows that $85.2 \%$ of shopping mall customers are youths, which confirms that the youths are the primary megamall users because they want to enjoy the moment's glitz and glamour. Senior citizens will prefer to patronize small retail shops than go to megamalls. This is because senior citizens may see such outings as a waste of time, energy, and resources. They will question the rationale of going to a mall, which may be long-distance than purchasing whatever they need in the retail store next door. However, on the contrary, youths see megamall shopping as an adventure, meeting point, sightseeing, eating place etc. On gender, the majority $(55.6 \%)$ of the respondents are male. The above findings were in tandem with the findings of Kuruvilla and Ranjan (2009) when they opined that men visited malls more than women and it refuted the assertions of Dholakai, Pedersen, and Hikmet (1995) as they opined that the ratio of shopping center usage between women and men is $2: 1$; which implies that shopping malls often appeal more to women than male. During the study, most people observed in the shopping malls were usually in two (male and female) who are just hanging out and having fun. Most customers of Megamall use it as a form of leisure. On the level of education, most of the respondents (80.1\%) fell in the tertiary education level and ranked the highest. This finding confirms that Megamall is a significant part of the modernization process, with people who had formal education/western education is oriented towards it. On monthly income, a higher percentage of the respondents $(32.4 \%)$ earn $\# 20,000-\# 40,000$. This shows that a higher percentage of megamall users are not affluent. This could be explained by the fact that some could be students and unemployed graduates, apprentices, or self-employed youths trying to earn meets.

The majority of the megamall customers earned below \#80,000 monthly. Ordinarily, such people should use the local shops/markets for their daily needs, but because of the need to 'feel among' and "show off,"; they still spend their meager income on frivolities mall. Most youths want to impress their friends, relatives, and fans by going to the megamalls. Some of the megamall users go there to take pictures and post on social media so that they, too, will be admired and approved. This is also revealed by Sohail (2015), Jih and Lee (2004) and Jewel, (2001). Megamalls depict a lifestyle that is endearing to everyone as a desirable place to be.

Olawale Yinusa Olonade, Dauda Aderemi Busari, David Imhonopi, Tayo Ola George, Charles Tunde Iruonagbe and Christiana Olufunke Adetunde (2021), IBIMA Business Review DOI: 10.5171/2021.280834 
Hence, every individual, irrespective of their socio-

economic status, wants to be part of it.

Table 1: Sociodemographic characteristics of the respondents

\begin{tabular}{|l|l|l|}
\hline Variables & Frequency & Percentage \\
\hline Age & & \\
$15-24$ & 83 & 38.4 \\
$25-34$ & 101 & 46.8 \\
$35-44$ & 18 & 8.3 \\
$45-54$ & 8 & 3.7 \\
55 and above & 6 & 2.8 \\
Total & $\mathbf{2 1 6}$ & $\mathbf{1 0 0}$ \\
\hline Gender & & \\
Male & 120 & 55.6 \\
Female & 98 & 44.4 \\
Total & $\mathbf{2 1 6}$ & $\mathbf{1 0 0}$ \\
\hline Educational Qualification & & \\
Primary & 3 & 1.4 \\
Secondary & 16 & 7.4 \\
Tertiary & 173 & 80.1 \\
Others & 23 & 11.1 \\
Total & $\mathbf{2 1 6}$ & $\mathbf{1 0 0}$ \\
\hline Respondent's monthly income & & \\
Less than \#20,000 & 42 & 19.4 \\
\#20,000-40,000 & 32.4 \\
\#41,000-60,000 & 70 & 15.3 \\
\#61,000-80,000 & 9.7 \\
\#81,000-above & 23.2 \\
Total & 21 & $\mathbf{1 0 0}$ \\
\hline
\end{tabular}

Source: Authors' Fieldwork, 2018.

Table 2 presents respondents' time frame of mall visit; $23.1 \%$ of respondents only visited malls in less than a year, $27.3 \%$ of respondents had visited the mall for $12-24$ months, $17.1 \%$ of respondents opined they have visited the mall up to 36 months, while $32.4 \%$ of respondents opined they have visited the malls for over 36 months. This implies that a higher percentage of the respondents $(32.4 \%)$ have been visiting the malls.

Table 2: How long respondents have been visiting malls

\begin{tabular}{|l|l|l|}
\hline The time frame of respondents' visit to the mall & Frequency & Percentage \\
\hline Less than one year & 50 & 23.1 \\
12-24months & 59 & 27.3 \\
25-36months & 37 & 17.1 \\
36months and above & 70 & 32.4 \\
Total & $\mathbf{2 1 6}$ & $\mathbf{1 0 0}$ \\
\hline
\end{tabular}

Source: Authors' Fieldwork, 2018.

Figure 1 below represents respondents' choice of shopping place; it shows that $89 \%$ of the respondents opined that malls are their choicest place of shopping, 7\% of the respondents opined that retail shops while $4 \%$ of the respondents opined that they prefer to shop in the open market. 
This implies that most of the respondents (89\%) opined that they prefer shopping in the malls. Megamall depicts conglomerates and chains of businesses in goods, services, vacation, and voluntary acts. The above findings are in tandem with the assertion of Omoniyi (2018). They represent various shops and wares lined up for purchase, fun catching, sightseeing, relationship building, and business transacting.

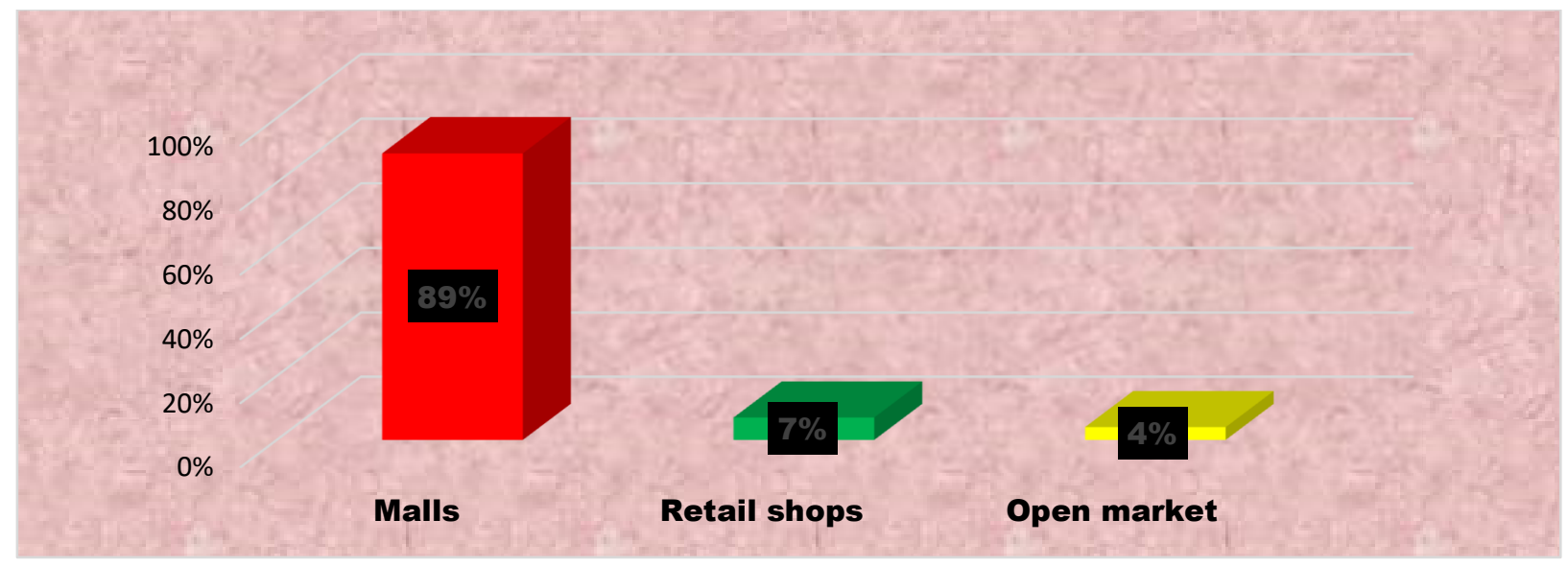

Figure 1: Percentage of respondent choice of shopping place

Source: Authors' Fieldwork, 2018.

Table 3 presents the respondents' rationale for their above choice. The result shows that a higher percentage of the respondents (38.4\%) opined that they choose shopping malls because they provide quality and affordable goods at your doorstep. Other rationales include the opportunity to have fun/hangout, meet different people from different places, serve as a recreational center, and get almost all you want in a single location. By implication, respondents value their time and shopping experience on every visit to the mall. Megamalls provide all these opportunities which retail shops and open markets do not offer. It allows them to exhibit their shopaholic and ostentatious lifestyles. The above finding further collaborates with the qualitative data as some of the respondents interviewed had this to say:

We stock consumable goods and non-consumable goods, basically food, beverages, household goods, toiletries, and liquor drinks. We offer recreational services like film houses, game arcades, bar and launch restaurant services, and shopping malls. Other side attractions include fastfood restaurants, superstores, and the likes. We sell clothes, shoes, and bags while the fifth participants gave a detailed description of what they sell in their mall. So virtually everything people need can be gotten in the mall. (Male/IDI/Mall operators/2018).

Another response by another respondent succinctly captures the distinction of malls and why people patronize malls more than retail shops, these were her direct words:

Whatever people buy here, they can be sure they are genuine and original. It is rare to find fake things in the mall, unlike all these shops in the neighborhood or local markets. Shopping malls have names they want to protect, so people have the benefits of getting original stuff here at affordable prices. Also, there is enough space to accommodate the crowd from coming here. Malls have a sitting arrangement where people can wait and relax. Malls 
also have many toys in their children's section where children who come with their parents can stay while the parents go shopping. There is also a large parking lot that can accommodate many of their customers' cars. All these are hardly found in many of these neighborhood shops. Also, the goods and services are reliable, people cannot come across fake things, and they are all affordable. Malls keep their environment safe and serene for customers to enjoy their shopping. This is a one-stop destination where one can get all their goods in a single place at affordable prices. Hence, Megamall provides shoppers the opportunity to get all they need in one place than what one can get in retail shops. (Female/IDI/Mall customer/2018).

The above assertion connotes that the fact that customers have the opportunity to buy several and various items in a single shop goes a long way to influence their choice of malls than retail shops or open markets. Customers often buy items they did not even plan to buy in the first place because they saw such items, and they were appealing to them.

Table 3: Respondents' rationale for their choice of shopping

\begin{tabular}{|l|l|l|}
\hline The rationale for the choice of shopping & Frequency & Percentage \\
\hline Malls provide an opportunity to have fun/hangout & 53 & 24.5 \\
\hline $\begin{array}{l}\text { Malls provide an opportunity to meet different people } \\
\text { from different places }\end{array}$ & 31 & 14.4 \\
\hline Malls serve as a recreational center & 17 & 7.9 \\
\hline $\begin{array}{l}\text { Malls provide quality and affordable goods at your } \\
\text { doorstep }\end{array}$ & 83 & 38.4 \\
\hline In malls, you get almost all you want in a single location & 32 & 14.8 \\
\hline Total & $\mathbf{2 1 6}$ & $\mathbf{1 0 0}$ \\
\hline
\end{tabular}

Source: Authors' Fieldwork, 2018.

Figure two below presents how often respondents visit malls in the Ibadan metropolis. The result shows that $24.5 \%$ of the respondents visit malls very often, $22.7 \%$ of the respondents opined that they visit the malls somewhat often, and $33.4 \%$ of the respondents often visit the mall, while $19.4 \%$ of the respondents visit the malls not very often. This is an indication that the majority of the respondents often visit the mall. 


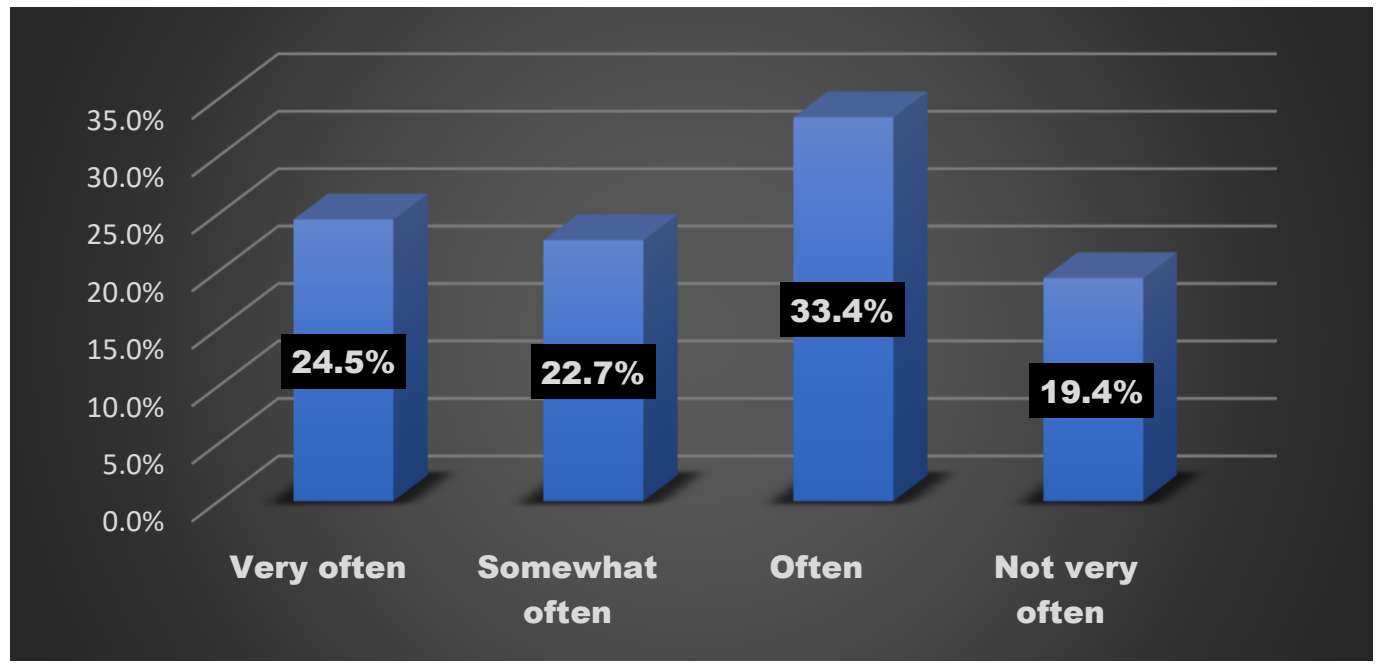

Figure 2: Percentage of respondents' response on how often they visit the mall Source: Authors' Fieldwork, 2018.

The experiences of the megamall users were ascertained in the cause of the study. Respondents rated their experiences in the Megamall based on their past outings and visits to the megamalls. Table two below presents the respondents' opinions on what they experience about the megamalls. The respondents' experiences in the malls, the majority of the respondents $(87 \%)$ opined that they were highly satisfied with their shopping experiences. This satisfaction could be explained by the fact that most customers visit the shopping malls to have fun and meet people apart from shopping. The above assertion is collaborated with the qualitative finding as to the mall operators/managers. One of the respondents interviewed had this to say:

We maintain good customer service. Customers are our priority here. We make sure that they are satisfied, and if the customers make any complaints, we treat it as urgent and make sure that such a thing does not occur again. (IDI/Mall operator/2018)

From the above assertion, the place of good customer service is a priority in the mall. This follows the saying that "customers are kings". That could explain why malls are experiencing extensive patronage, unlike the small retail shops.
Moreover, people like to go where they are treated well, appreciated, and valued, unlike places.

Another respondent interviewed had this to say:

We make sure we stock quality goods here, keep our environment clean, have business cards for each of our clients, and sponsor T.V. shows on celebrities and lifestyles. Also, we make sure that customers and their properties are safe. We cherish our customers, and we offer promotional activities periodically, especially in our film house. We are also very active on social media to showcase what we have in the mall. (IDI/Mall operator/2018)

From the above assertion, malls endeavor to sell quality goods, one of the customers' attractions. When people trust their products, they will keep coming. This is because people want value for their "hard-earned" money in Nigeria. Also, mall operators ensure that their customers and their properties are safe, that is an excellent strategy to ensure continued patronage to the mall. People will not continue to go to megamalls if such an environment is unsafe and unsecured. Invariably, megamall customers keep going there because they consider it safe and secure. Also, one of the 
customers interviewed had this to say about her experience in the mall.

This mall is very helpful to people as it eases them the stress of struggling in the local market. I mean that here in this Megamall you come in and get all you need in a place. Unlike the open market where you walk from one end to another on a rough, dusty, and wrong road, here, even if you walk around, everywhere is clean and tiles, you are inside an air-conditional environment mall is cool and clean. So, I think that is why many people prefer to come here to other places. (IDI/Mall customer/2018)

The above assertion explains why customers patronize malls more. The conducive and serene environment is one of the major factors why people patronize malls. Shopping in the mall exposes customers to less stress than shopping in the open market, where one has to move from one location to another before one could complete his/her shopping. The stress of moving from one location to another under hot weather conditions to shop is prevented and needless when shopping in the malls as the whole shopping malls are airconditioned and conducive. The above finding could also explain why respondents choose Megamall for other shopping alternatives because they are satisfied with the megamalls' services.

Table 3: Response of respondents on their experiences in the malls

\begin{tabular}{|l|l|l|}
\hline Response & Frequency & Percentage \\
\hline Highly satisfactory & 188 & 87 \\
\hline Not too satisfactory & 26 & 12 \\
\hline Below satisfaction & 2 & 1 \\
\hline Total & $\mathbf{2 1 6}$ & $\mathbf{1 0 0}$ \\
\hline
\end{tabular}

Source: Authors' Fieldwork, 2018.

Figure 3 below presents the percentage of respondents' perception of how innovative they think the malls are. The result shows that $20.8 \%$ of the respondents perceive the mall as extremely innovative; a higher percentage $(46.3 \%)$ of the respondents opined that malls are very innovative; $25 \%$ of the respondents are somewhat innovative; $7 \%$ of the respondents opined that malls are not so innovative; while $0.9 \%$ of the respondents stated that malls are not innovative at all. 


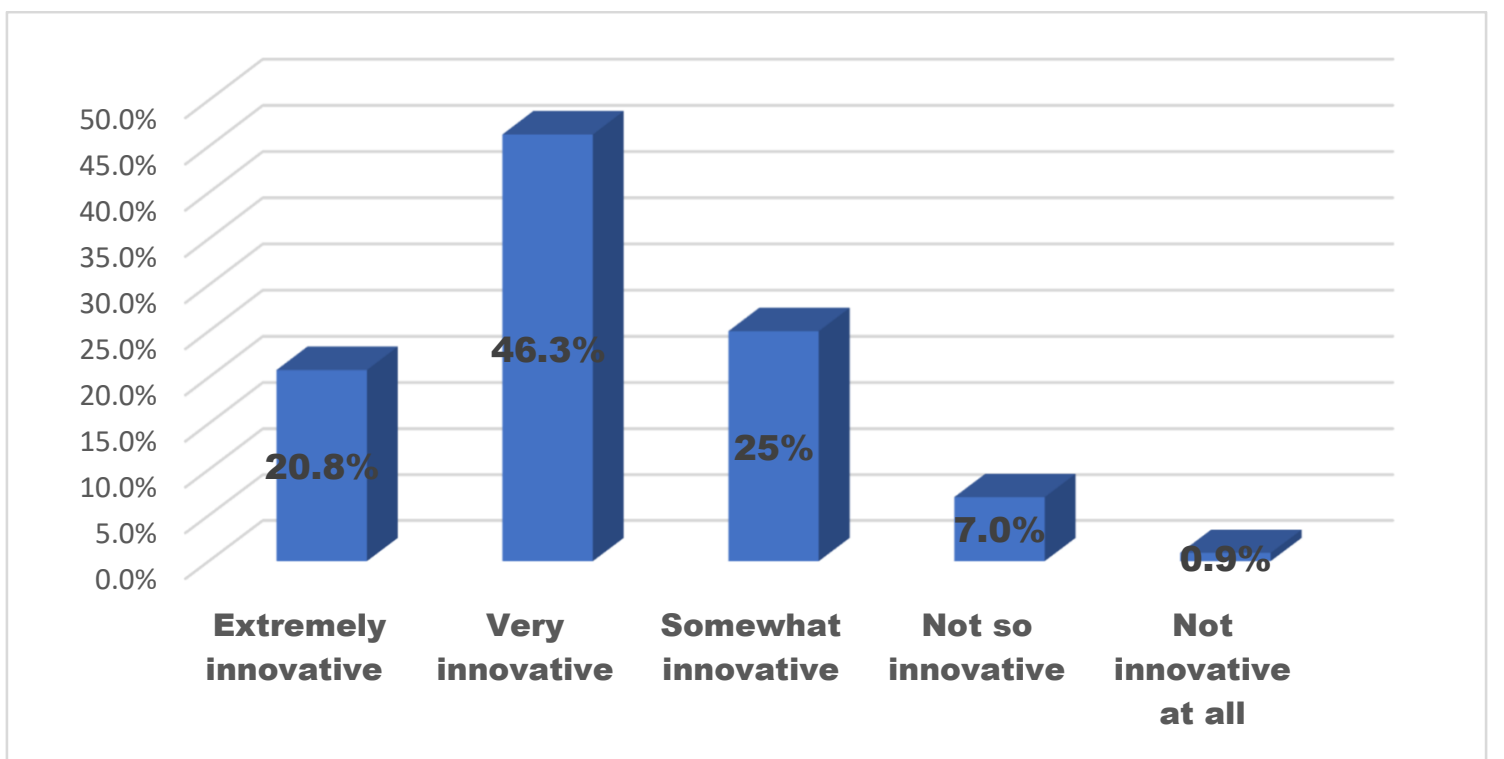

Figure 3: Percentage of respondents' perception of how innovative they think the malls are

Source: Authors' Fieldwork, 2018.

\section{Conclusion}

Based on this article's findings, megamalls have developed due to the shopaholic nature of most urban dwellers. A conducive and serene environment is one of the major factors why people chose Megamall against retail shops and open markets which has contributed to the megamalls' development in no small measure. As it may, that does not mean that urban residents have stopped patronizing retail shops and open markets but have minimized their patronage of retail shops and open markets and increased their patronage of megamalls. Moreover, shopping in the Megamall exposes customers to less stress than shopping in the open market, where one has to move from one location to another before one could complete his/her shopping. The stress of moving from one location to another under hot weather conditions to shop is prevented and needless when shopping in the malls as the whole shopping malls are airconditioned and conducive.

Customers of Megamall chose Megamall against other shopping alternatives because Megamall can buy several and diverse items in a single shop, which goes a long way to influence their choice of malls than retail shops or open markets. Customers often buy items they did not even plan to buy in the first place because they saw such items, and it was appealing to them. Shopping malls also provide quality and affordable goods at your doorstep. Other rationales include the opportunity to have fun/hangout, meet different people from different places, serve as a recreational center, and get almost all consumers to meet and connect in a single location, amongst others. By implication, customers of megamalls are getting value for their time and shopping experience as they visit the malls. Megamalls provide all these opportunities which retail shops and open markets do not offer. They allow them to exhibit their shopaholic and ostentatious lifestyles. Although Megamall contributes to the socio-economic development of the Ibadan metropolis, the importance and contributions of retail shops and open markets should not be downplayed.

\section{Acknowledgment}

The authors appreciate Covenant University Centre for Research Innovation and Discovery (CUCRID) for their support for conferences and publication fees

\section{Reference}

- Bidandi, F., and Williams, J.J. (2017). Architecture and planning, research article the terrain of urbanization process and policy framework: a critical analysis of the kampala experience. 
- Cezar, M., (1983). Typical Commercial Buildings of the Ottoman Classical Period And The Ottoman Construction System. Istanbul: Kultur Yayinlari

- Chukuezi, C.O. (2010). Entrepreneurs of the streets: Socio-economic features of street food vending in Owerri, Nigeria. European Journal of Social Sciences, 14 (2): 183-188.

- Cohen, B. (2006). Urbanization in Developing Countries, Current Trends, Future Projections, and Key Challenges for Sustainability. Technology in Society 28 (1-2), pp. 63-80.

- Creel, J.S. (2006). The availability of healthy food options in fast food outlets in six rural countries submitted to the office of Graduate Studies of Texas A. and M. University in partial fulfillment of the requirements for the degree of masters of sciences.

- Busari, D. A; Olonade, O. Y., Asamu, F. F. (2019). Megamalls as Site for Social Interaction: A Study of Shoprite and Ventura, Ibadan, Nigeria. Applied Research Journal of Humanities and Social Sciences. Vol2(2) pp. 617 August, 2019

- Egharevba, M. E., Eguavon, A., Azuh, D., Iruonagbe, C. T. \& Chiarzor, I. A. (2016). Microfinance and Poverty Reduction Strategy for Promoting National Development: The Challenge of Social/Fiancial Inclusion. Social Sciences, 11(22)5373-5386. Medwell Journal, Pakistan.

- Ferdman, A. (2018). Perfectionist Public Space: A political philosophy approach. Space and Polity. Volume 22.

- Gürçel, C. (2003). Integration of shopping malls with pedestrian environment: an analysis of akkopru migros and karum shopping malls. A thesis submitted to the department of interior architecture and environmental design and the institution of fine arts of bilkent university in partial fulfillment of the requirements for the degree of master of fine arts.

- Hamil and Thanaraj, X.A. (2011). Impact of Supermarkets on Small Retailers in Indian Suburb, IJMMR, Volume 2, Issue 6, pp. 1-12
- Isibor, A.A., Omankhanlen, A.E., Okoye, L. U, Afolabi, G.T., Ayodeji, O.E. (2019). Impact of electronic banking technology on customers' satisfaction and economic growth in Nigeria. International Journal of Civil Engineering and Technology. Volume 9, Issue 12, 1 December 2018, Pages 536-544

- Kendall, D., (2007). Sociology in our Times. Cengage Learning

- Miller, D., Jackson, P., Thrift, N., Holbrook B., and Rowlands, M. (1998) Shopping, Place and Identity. London: Routledge.

- Mukhola, M.S., (2007). Guidelines for an environmental education training programme for street food vendors in polokwane city. Available from: http:etd.rau.ac.za/theses/submitted/etd03132007-140510/restricted/last.pdf

- Munich, R.E. (2004). Megacities-Megarisks. Trends and Challenges for insurance and risk management, Munich.

- $\quad$ Njoroge, D.K., (1995). Mall Centres: A study of the Mall Shoppers Space Development, Design and Spatial Requirements.

- $\quad$ Omoniyi, S., (2018). Shopping Malls in Agbara. Ojasweb.com/adds/shopping-malls-agbara

- $\quad$ Rousseau, G.G., and Venter, D.J.L. (2014). Mall Shopping preferences and patronage of mature shoppers. S.A. Journal of industrial Psychology 40 (1)

- $\quad$ Rousseau, V.V and Venter, D.J.L. (2014). Mall shopping preferences and patronage of mature shoppers. S.A. Journal of Industrial Psychology 40 (1)

- Talwar, J., (2003). Fast Food, Fast Track: Immigration, Big Business, and the American Dream. Westview Press. ISBN 0-8133-41558

- United Nations Population Division, (2006). World Urbanization Prospects: The 2005 Revision. New York.

- White, R. and Sutton, A. (2001). Social Planning for Mall redevelopment. An Australian casestudy. Local Environment, 6(1) 65-80 